February 2002 - NREL/TP-540-31479

\title{
Natural Gas in Transit Fleets: A Review of the Transit Experience
}

Leslie Eudy

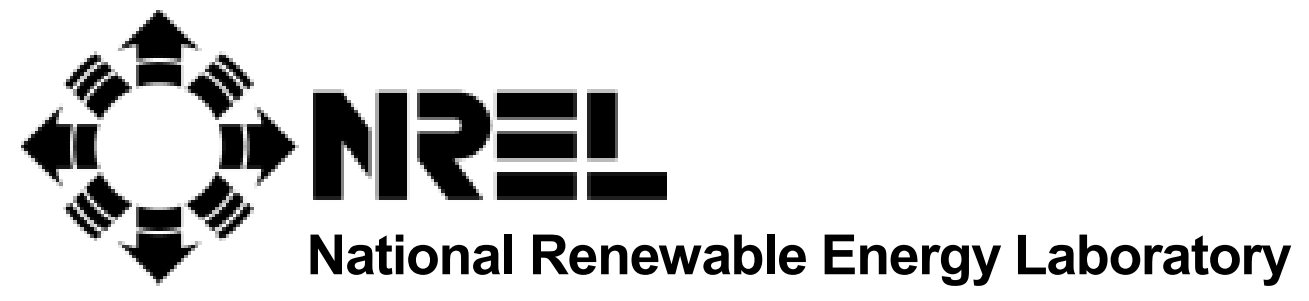

1617 Cole Boulevard

Golden, Colorado 80401-3393

NREL is a U.S. Department of Energy Laboratory

Operated by Midwest Research Institute • Battelle • Bechtel

Contract No. DE-AC36-99-G010337 


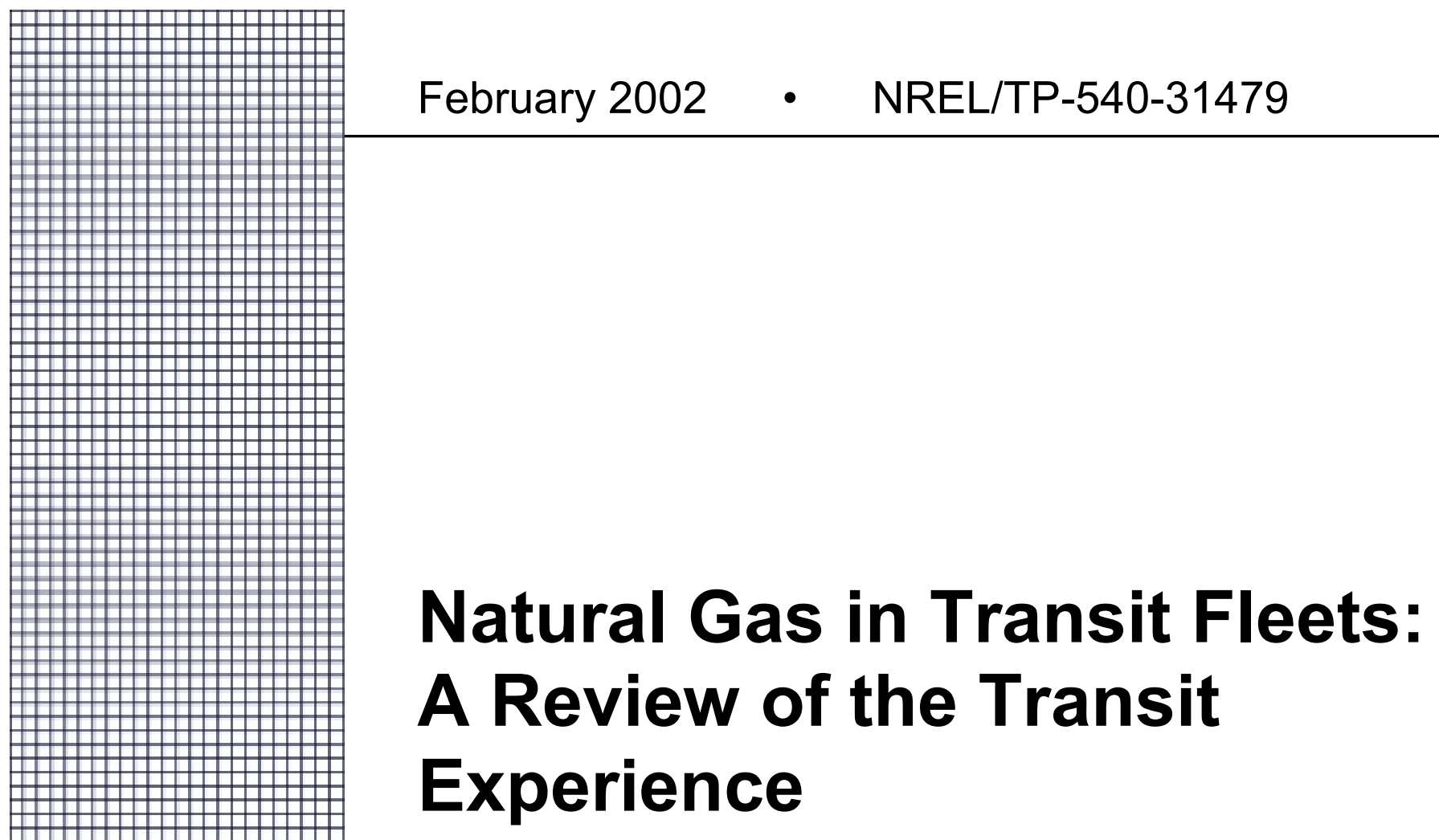

\section{Leslie Eudy}

Prepared under Task No. FU23.5620

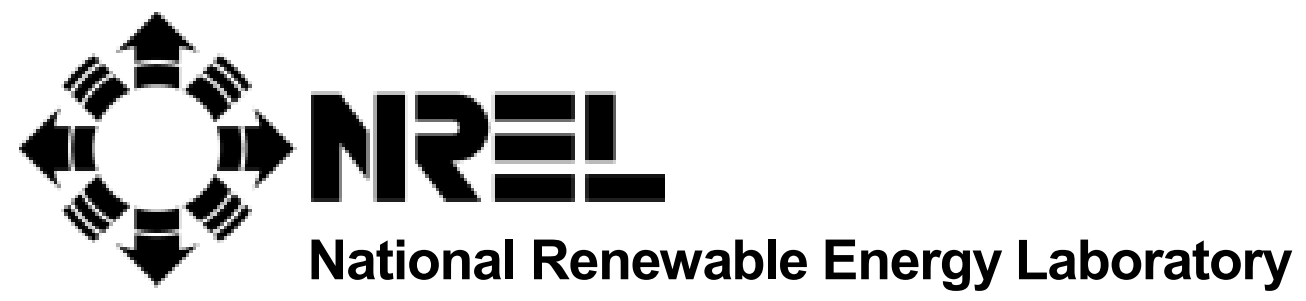

1617 Cole Boulevard

Golden, Colorado 80401-3393

NREL is a U.S. Department of Energy Laboratory

Operated by Midwest Research Institute • Battelle • Bechtel

Contract No. DE-AC36-99-G010337 


\section{NOTICE}

This report was prepared as an account of work sponsored by an agency of the United States government. Neither the United States government nor any agency thereof, nor any of their employees, makes any warranty, express or implied, or assumes any legal liability or responsibility for the accuracy, completeness, or usefulness of any information, apparatus, product, or process disclosed, or represents that its use would not infringe privately owned rights. Reference herein to any specific commercial product, process, or service by trade name, trademark, manufacturer, or otherwise does not necessarily constitute or imply its endorsement, recommendation, or favoring by the United States government or any agency thereof. The views and opinions of authors expressed herein do not necessarily state or reflect those of the United States government or any agency thereof.

Available electronically at http://www.osti.gov/bridge

Available for a processing fee to U.S. Department of Energy

and its contractors, in paper, from:

U.S. Department of Energy

Office of Scientific and Technical Information

P.O. Box 62

Oak Ridge, TN 37831-0062

phone: 865.576.8401

fax: 865.576 .5728

email: reports@adonis.osti.gov

Available for sale to the public, in paper, from:

U.S. Department of Commerce

National Technical Information Service

5285 Port Royal Road

Springfield, VA 22161

phone: 800.553 .6847

fax: 703.605.6900

email: orders@ntis.fedworld.gov

online ordering: http://www.ntis.gov/ordering.htm 


\section{Table of Contents}

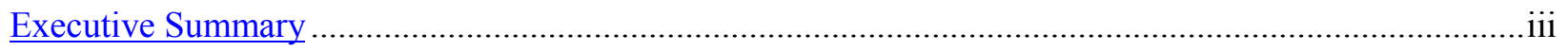

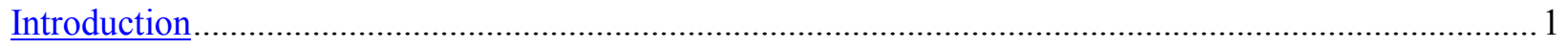

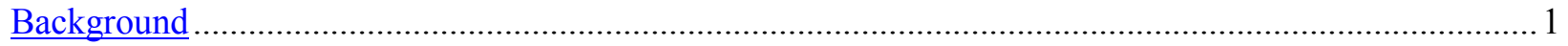

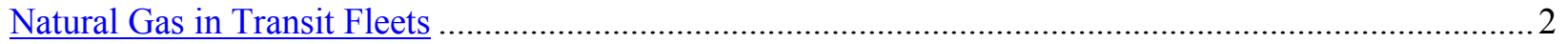

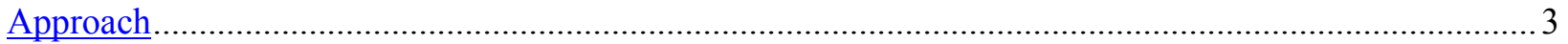

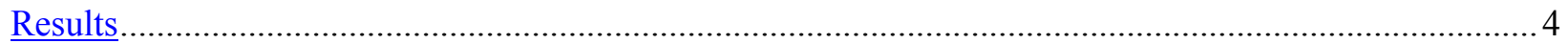

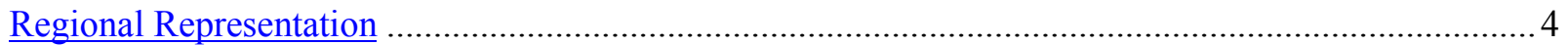

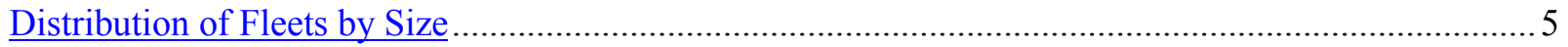

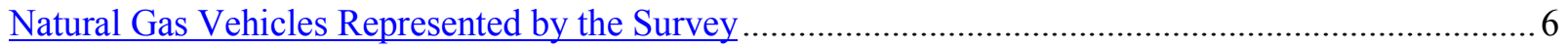

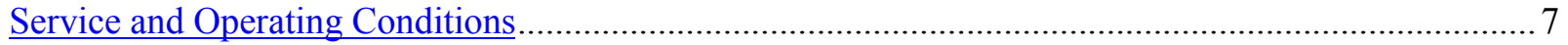

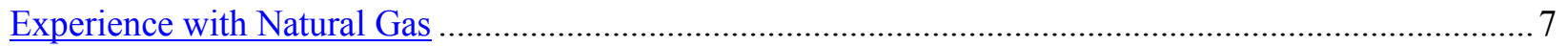

Fleet Size

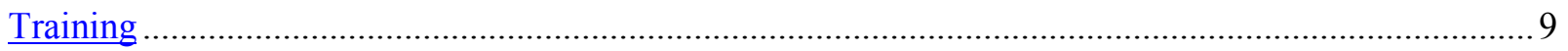

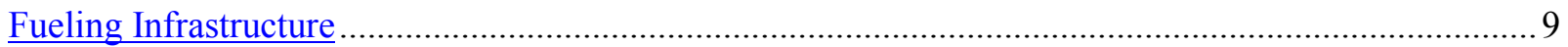

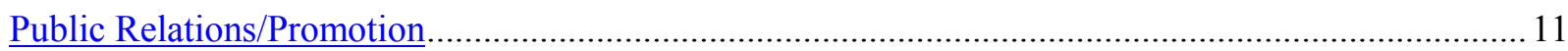

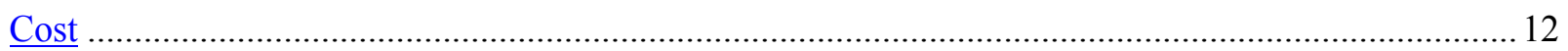

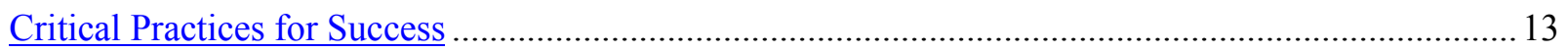

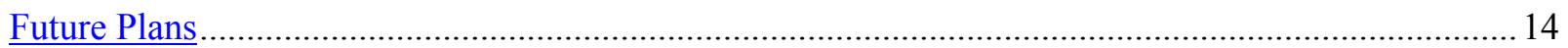

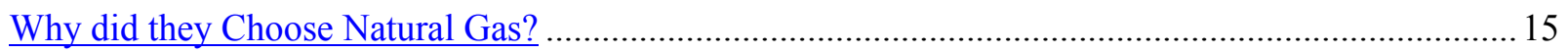

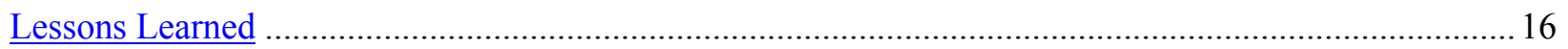

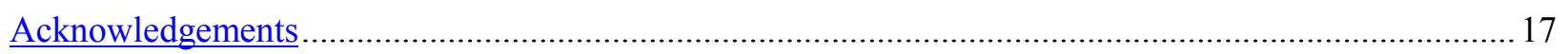

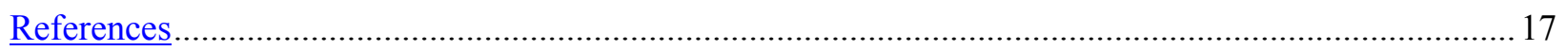

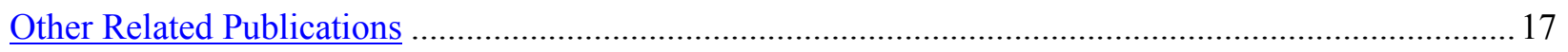

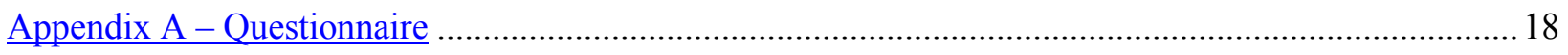

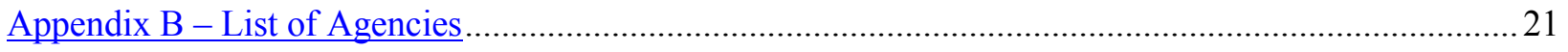

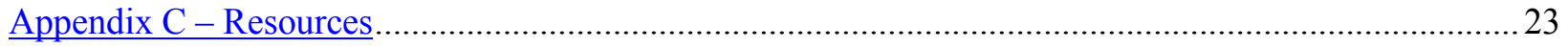


This page intentionally left blank. 


\section{Executive Summary}

Use of natural gas in transit bus fleets has grown over the last decade. Often motivated by air quality concerns, the use of natural gas also contributes to national and local energy security. Approximately $9 \%$ of the U.S. transit fleet in 2001 was composed of buses operating on some form of natural gas and even more were on order. While some agencies have achieved success with their natural gas programs, others report difficulties and some have suspended their natural gas use altogether. What makes an agency successful in implementing natural gas into their operations? This paper reviews the experience of agencies with natural gas to determine the answer and to provide guidance on how fleets can effectively duplicate the successes and address or avoid the challenges.

The mission of the U.S. Department of Energy's (DOE) Office of Transportation Technologies (OTT) is to promote the development and deployment of transportation technologies that reduce U.S. dependence on foreign oil, while helping to improve the nation's air quality and promoting U.S. competitiveness. The National Renewable Energy Laboratory (NREL) supports DOE's Field Operations Program within DOE's Office of Technology Utilization (OTU) in collecting and disseminating information that will assist potential purchasers of medium- and heavy-duty alternative fuel and advanced technology vehicles in making informed purchase and implementation decisions. NREL and others have published studies that document the experiences of individual transit agencies. This paper expands on the lessons learned from previous studies by examining a broader sample of fleets using natural gas buses.

From April to June 2001, through a contract with RP Publishing, NREL interviewed 42 transit agencies that have integrated natural gas buses into their operations. We analyzed the fleet responses to characterize the relative success of the programs, categorizing the programs as overall "Success fleets" or "Challenge fleets" to look for patterns that would help identify attributes that made certain programs successful.

The questionnaire used in the interviews was designed to gather information on basic demographics, such as fleet size and percentage of buses using natural gas, as well as on the agency's experience with operating and maintaining natural gas buses. Some important findings from the demographic analysis are:

- The buses represented by the respondents included 13,546 diesel (78.8\%), 3,209 CNG (18.7\%), and 430 LNG buses $(2.5 \%)$.

- Fleet size ranged from six buses to more than 4,500 buses, with an average fleet size of 409 buses.

- The size of the natural gas portion of each fleet ranged from two to more than 1,300 buses with an average of 87 buses.

- The percentage of natural gas buses in a fleet ranged from $1.4 \%$ to $100 \%$.

- $53 \%$ of the respondents reported a natural gas fleet that is $25 \%$ or less of their total fleet.

- $89 \%$ of the buses reported on were 40 -foot transit buses.

- $49.9 \%$ of the natural gas buses were powered by Detroit Diesel Corporation's Series $50 \mathrm{G}$ engine, and $32.2 \%$ were powered by Cummins Engine Company's L10G engine.

Several key factors were identified that can aid other transit agencies planning to add natural gas buses to their fleets. How an agency addresses these factors will likely determine its level of success. Key findings of the study were:

- Training is critical. A thorough training program for understanding and maintaining natural gas buses was most often cited as critical for success by fleet managers surveyed. Forty-two percent of the Success fleets credited their extensive training program as a reason for their success with natural gas buses. 
- Adequate fueling infrastructure is essential. Of the seven fleets interviewed that did not have on-site fueling, six reported predominantly negative experiences with natural gas. Half of the fleets in the Challenge category listed fuel availability or problems with fueling as reasons for their difficulties.

- Commitment to the program is of paramount importance. This includes all levels of the organization, from the boardroom to the maintenance garage. Forty-one percent of the fleets in the Success category listed their commitment as one reason for their positive experience.

- Promotion of the program can be a benefit. Many fleets reported positive response from the public in their operating areas. Seventy percent of the Success fleets reported promotion of their natural gas buses by signs or different color schemes. Thirty-three percent reported major campaigns to promote their programs to the public.

- Understanding the costs and planning ahead is also critical. Although natural gas buses typically cost more than diesel buses and require added fueling infrastructure and garage modifications, funding is available to help with the costs. Some fleet managers reported that the funding available to offset the incremental cost of alternative fuel buses and to add fueling infrastructure was a consideration in choosing natural gas buses. While several of the more seasoned CNG transit properties reported lower operating costs and even ongoing savings in specific areas, most fleets reported higher costs for operating and maintaining their natural gas buses.

- Approximately $25 \%$ of the buses currently on order are natural gas powered. Eighty-three percent of the Success fleets interviewed plan to purchase additional natural gas buses. Despite having difficulties integrating natural gas into their operations, half of the Challenge fleets also plan to purchase additional natural gas buses.

- In a follow-up survey of high-level managers asked about their agency's experience with natural gas, the majority $(60 \%)$ of high-level managers felt that their programs were successful. Another $32 \%$ felt that their experience with natural gas technology was mixed, while only $8 \%$ felt their programs were not successful.

Even with the challenges involved, transit fleets are moving ahead with purchases of natural gas buses to reduce emissions and provide community benefits in their areas. For a fleet that takes into account the lessons learned by others, experience shows that transit agencies can be successful with natural gas, meaning they can help improve air quality and energy security in their regions, as well as provide solutions to local challenges. 


\section{Introduction}

During the last decade, transit agencies across the nation have begun to use natural gas to fuel their buses. Some agencies have been successful and are moving toward an all natural gas fleet; others have faced operational or financial challenges. Opinions within the industry are often polarized. Both camps can cite examples to support their opinions. By analyzing the experiences of as many fleets as possible, we tried to develop a more complete view of the transit industry's experience with natural gas and identify the critical ingredients for successful fleets.

The mission of the Department of Energy's (DOE) Office of Transportation Technologies (OTT) is to promote the development and deployment of transportation technologies that reduce U.S. dependence on foreign oil, while helping to improve the nation's air quality and promoting U.S. competitiveness. The National Renewable Energy Laboratory (NREL) supports DOE's Field Operations Program within DOE's Office of Technology Utilization (OTU) in collecting and disseminating information that will assist potential purchasers of medium- and heavy-duty alternative fuel and advanced technology vehicles in making informed purchase and implementation decisions.

This report summarizes the results of a survey of 42 transit agencies that have experience operating natural gas buses in their fleets. The results contain information about the types of agencies operating natural gas buses and provide information about their successes, difficulties, and lessons learned. We analyzed this information utilizing our experience with evaluating alternative fuel fleets. NREL, through its subcontracting partner, Battelle, has been collecting detailed information on alternative fuel urban transit buses since 1993. The experiences of the NREL evaluation fleets have shown that several factors contribute to successfully integrating natural gas buses into a fleet. While there is no one blueprint for success that will work for all agencies, transit operators can use the experiences compiled in this document to plan a strategy that can be successful for their organizations.

\section{Background}

Although natural gas buses have been in operation for more than a decade and their use is growing, they comprise less than $10 \%$ of the nationwide transit bus population in service today. This is partially because buses are typically kept in service for 10 to 12 years or more and only a small portion of the total transit base (around 6\%) is replaced each year, so it takes considerable time for any technology change to become truly widespread throughout this industry. The use of alternative fuels in buses, as well as other vehicle applications, began mainly in response to Federal laws passed in an effort to reduce dependence on foreign petroleum and improve air quality. The most important of these laws were the Alternative Motor Fuels Act of 1998 (AMFA), the Clean Air Act Amendments of 1990 (CAAA), and the Energy Policy Act of 1992 (EPAct).

AMFA encouraged the development, testing, and demonstration of alternative fuel vehicles (AFVs). This act included a provision for DOE to assist state and local government agencies in testing alternative fuel buses in urban settings.

CAAA established the Clean Fuel Fleet Program, which requires cities with significant air quality problems to promote vehicles that meet a strict set of emission standards. Section 7554 of the Act set emission standards for buses beginning with model year 1994.

EPAct promoted the use of AFVs in Federal, state and alternative fuel provider fleets in an effort to reduce U.S. dependence on foreign oil. DOE's National Clean Cities Program, a voluntary initiative, was designed to achieve the objectives of EPAct. Many transit agencies are members of Clean Cities coalitions and are eligible for funding opportunities (for more information, see Appendix C). 
Several states also passed laws governing the vehicle purchases of transit agencies. For example, Texas passed legislation that required $30 \%$ of transit agency vehicles to use cleaner (reduced emission) technologies by September of 1991. More recent regulations include California's Transit Bus Fleet Rule, which requires agencies in the state to take steps toward meeting increasingly stringent emissions requirements for 2007 and beyond. In order to meet these requirements, transit agencies may select one of two paths: clean diesel or alternative fuel. Both paths require a retrofit of "older" diesel vehicles with updated emission control devices, use of low-sulfur fuel in diesel buses, and eventual adoption of zero emission vehicles. The distinction comes with the acquisition of "new" buses, with the diesel path focusing on the purchase of vehicles that use advanced (reduced sulfur) diesel emission control systems and the alternative fuel path focusing on buses that use alternative fuels exclusively. For more information about this rule, see http://www.arb.ca.gov/msprog/bus/bus.htm. Federal funding for many of these projects was available through agencies such as the Federal Transit Administration.

\section{Natural Gas in Transit Fleets}

Each year, the American Public Transportation Association (APTA) collects information from transit agencies on the buses they operate. One of the products produced is a compendium of alternative fuel and advanced technology buses being used in fleets around the country. In 1994, APTA estimated that approximately $1.3 \%$ of the U.S. transit fleet was composed of buses that operated on natural gas and natural gas blends. According to APTA's most recent compendium (January, 1, 2001), there are 73 fleets in the U.S. using a total of 4,998 natural gas buses in revenue service, making up $9 \%$ of the U.S. transit fleet. Based on bus orders reported to APTA, that number will continue to grow. Table 1 features the numbers of active buses as well as the planned orders. Assuming all potential orders are placed, the percentage of natural gas buses in the fleet will climb to $12.8 \%$ of the total by 2005 . However, the transition is much more dramatic if you consider that certain regions of the country and specific fleets have much more aggressive natural gas programs than others. About $25 \%$ of all new buses on order are natural gas, and a number of fleets report that $100 \%$ of their new bus purchases will be natural gas.

Table 1. Natural Gas Buses in the U.S. Fleet (Reported to APTA as of 1/1/01)

\begin{tabular}{|l|c|c|c|c|c|c||}
\hline & CNG & LNG & Total NG & Others $^{*}$ & Diesel & Total \\
\hline Active buses & 4,153 & 845 & 4,998 & 421 & 49,771 & 55,190 \\
\hline $\begin{array}{l}\text { On order (contract } \\
\text { awarded) }\end{array}$ & 1,677 & 135 & 1,812 & 54 & 5,393 & 7,259 \\
\hline $\begin{array}{l}\text { Potential orders } \\
\text { (contract not awarded) }\end{array}$ & 2,385 & 465 & 2,850 & 1,412 & 8,983 & 13,245 \\
\hline Total & $\mathbf{8 , 2 1 5}$ & $\mathbf{1 , 4 4 5}$ & $\mathbf{9 , 6 6 0}$ & $\mathbf{1 , 8 8 7}$ & $\mathbf{6 4 , 1 4 7}$ & $\mathbf{7 5 , 6 9 4}$ \\
\hline
\end{tabular}

* Includes all other fuels (Battery electric, gasoline, alcohol, propane, jet fuel, and hydrogen)

Because emission levels have been tightened considerably over the last decade, and because many of the urban areas where transit buses typically operate have often been designated as nonattainment areas for criteria air pollutants by the Environmental Protection Agency (EPA), some transit agencies have chosen natural gas specifically because of its potential to lower emissions. (Figure 1 shows the change in certification standards for urban bus engines from 1990-2007.) In the ongoing attempt to improve air quality, regulators often look to highly visible transit fleets to set an example by encouraging them to use a clean fuel. However, political pressure to switch to natural gas has resulted in some fleets purchasing natural gas buses without all the information needed to make the change successfully. In addition to technical information on the buses, their operation, and infrastructure, a fleet must make a strong commitment to build a successful natural gas bus program. Without these, the chance of successful integration for natural gas is reduced. 


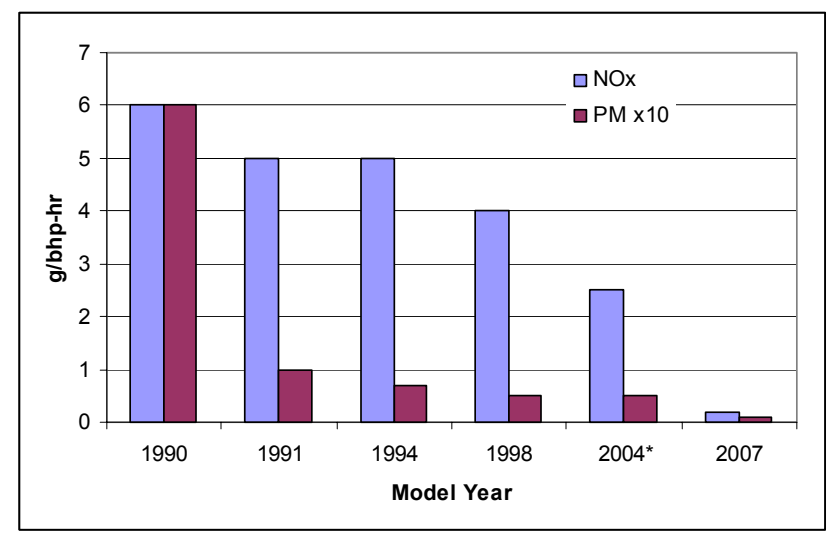

Figure 1. Federal Certification Levels for Urban Bus Engines

*For 2004, NMHC and NOx are combined

\section{Approach}

One of the best ways to learn how to successfully implement alternative fuel buses is to learn from the agencies that have used the technology. Their experiences, both successes and challenges, can aid other agencies wanting to implement a new technology into a fleet. To collect this information, we conducted phone interviews. RP Publishing of Denver, Colo., helped NREL develop the questionnaire and administered the survey (see Appendix A). Without these, the chance of successful integration for natural gas is reduced. RP Publishing has nine years experience with alternative fuel vehicles and technologies through the publication of magazines such as Natural Gas Fuels Magazine, Propane Vehicle Magazine, and Advanced Vehicle 2001.

The questionnaire was designed to gather information in several categories;

- Demographics: questions pertaining to vehicle numbers, fleet size, service type, and regional operating conditions.

- Vehicle Matrix: specific questions about the buses, such as engine manufacturer and model, and purchase cost.

- Operations: average miles between road calls, special training for fleet personnel, and promoting natural gas buses.

- Fueling: questions about how the fleet fuels the natural gas buses, including on-site versus off-site fueling, details on cost and operation of fueling stations (including direct ownership vs. third party leasing or special fuel provider agreements), and reasons surrounding the addition of a fueling site.

- Overall experience: questions about the successes and challenges encountered and what was most critical for successfully implementing natural gas buses.

Fifty-three agencies were contacted, 42 of which currently use natural gas buses. The phone interviews were conducted between April and June 2001. The survey respondents provided candid opinions about natural gas buses and their experiences. Because these opinions of individuals sometimes were contrary to their particular agency's publicly expressed views, we chose not to link the individual responses with the specific agency. Once the interviews were completed, the responses were entered into a spreadsheet and analyzed. The vehicle matrix was compared to the APTA 2001 Vehicle Database to validate the survey 
data, especially with respect to model year and vehicle type. APTA's yearly Vehicle Database is an extensive compilation of statistics on the transit fleets operating in North America and is based on information reported by each agency. APTA estimates the agencies included in the 2001 Vehicle Database account for about $70 \%$ of all transit vehicles. Of the transit agencies we questioned, only seven were not included in the APTA 2001 issue.

Two additional questionnaires were completed with transit agencies from our original list. The first follow-up questionnaire was designed to gather additional information from transit managers on their experience with the natural gas engines and training performed by the different engine manufacturers. The second follow-up questionnaire was targeted at high-level managers. These managers were asked why their agencies chose natural gas vehicles for their fleets and if the project was considered a success and why. The questionnaires can be found in Appendix A.

\section{Results}

We interviewed 53 fleet operators, 46 of which were a part of APTA's compendium of alternative fuel buses. The respondents represent a total of 3,639 natural gas buses. Seventy-nine percent of the respondents (42 of 53) reported that their organizations currently use natural gas buses. Eleven of the respondents reported that they did not currently operate natural gas buses. These fleets were asked a separate set of questions pertaining to their past experience and future plans. Of these agencies, nearly half (5 of 11) have experience with alternative fuel buses: One agency currently operates propanepowered buses, and the rest have experience with natural gas buses. Positive public awareness and community support were cited as strong motivators for considering and/or expanding natural gas programs as well as environmental and energy security benefits while higher costs were the most common reason given for those who had discontinued their programs. Clearly there are some constructive lessons to be learned from both these positive and negative experiences. The following sections present the results of the survey for 42 fleets that are currently operating natural gas buses.

\section{Regional Representation}

The respondents participating in the study show a fairly representative coverage of the U.S. by region. Twenty-three states are represented by at least one transit agency in the survey. California had the most respondents at 14 . This is not surprising, considering the tighter emission standards and recently passed regulations governing the California agencies. (For a complete list of participating agencies, see Appendix B.) Table 2 shows the number of respondents by region. The western region had the highest percentage of respondents at $47.6 \%$, followed by the southern region at $19 \%$.

\section{Table 2. Total Number of Respondents by U.S. Region}

\begin{tabular}{|l|c|c||}
\hline Region & $\begin{array}{c}\text { Number of } \\
\text { Respondents }\end{array}$ & $\begin{array}{c}\text { Percent of } \\
\text { Respondents }\end{array}$ \\
\hline Northeast & 7 & 16.7 \\
\hline South & 8 & 19.0 \\
\hline Midwest & 7 & 16.7 \\
\hline West & 20 & 47.6 \\
\hline Total & $\mathbf{4 2}$ & $\mathbf{1 0 0}$ \\
\hline
\end{tabular}

Table 3 shows the total number of buses operated by the survey participants. The vehicles are categorized by fuel type and U.S. region along with the percent of the total for each fuel type. The majority of buses operated by the agencies were diesel powered. Compressed natural gas (CNG) buses made up nearly 19\% of the total and LNG only $2.5 \%$ of the total. The numbers reported by the agencies reflect their fleet totals as of the date of the survey (April-June 2001). In addition, many managers reported that they had ordered more natural gas buses. Figure 2 shows the number of agencies interviewed and total number of natural gas buses by state and region. 
Table 3. Number of Buses by Fuel and Region

\begin{tabular}{||l|c|c|c|c||}
\hline Region & CNG & LNG & Diesel & Total by Region \\
\hline Northeast & 365 & 0 & 5,736 & $\mathbf{6 , 1 0 1}$ \\
\hline South & 464 & 174 & 1,830 & $\mathbf{2 , 4 6 8}$ \\
\hline Midwest & 262 & 8 & 2,078 & $\mathbf{2 , 3 4 8}$ \\
\hline West & 2,118 & 248 & 3,902 & $\mathbf{6 , 2 6 8}$ \\
\hline Total by fuel & $\mathbf{3 , 2 0 9}$ & $\mathbf{4 3 0}$ & $\mathbf{1 3 , 5 4 6}$ & $\mathbf{1 7 , 1 8 5}$ \\
\hline Percent by fuel & $\mathbf{1 8 . 7 \%}$ & $\mathbf{2 . 5 \%}$ & $\mathbf{7 8 . 8 \%}$ & $\mathbf{1 0 0 \%}$ \\
\hline
\end{tabular}

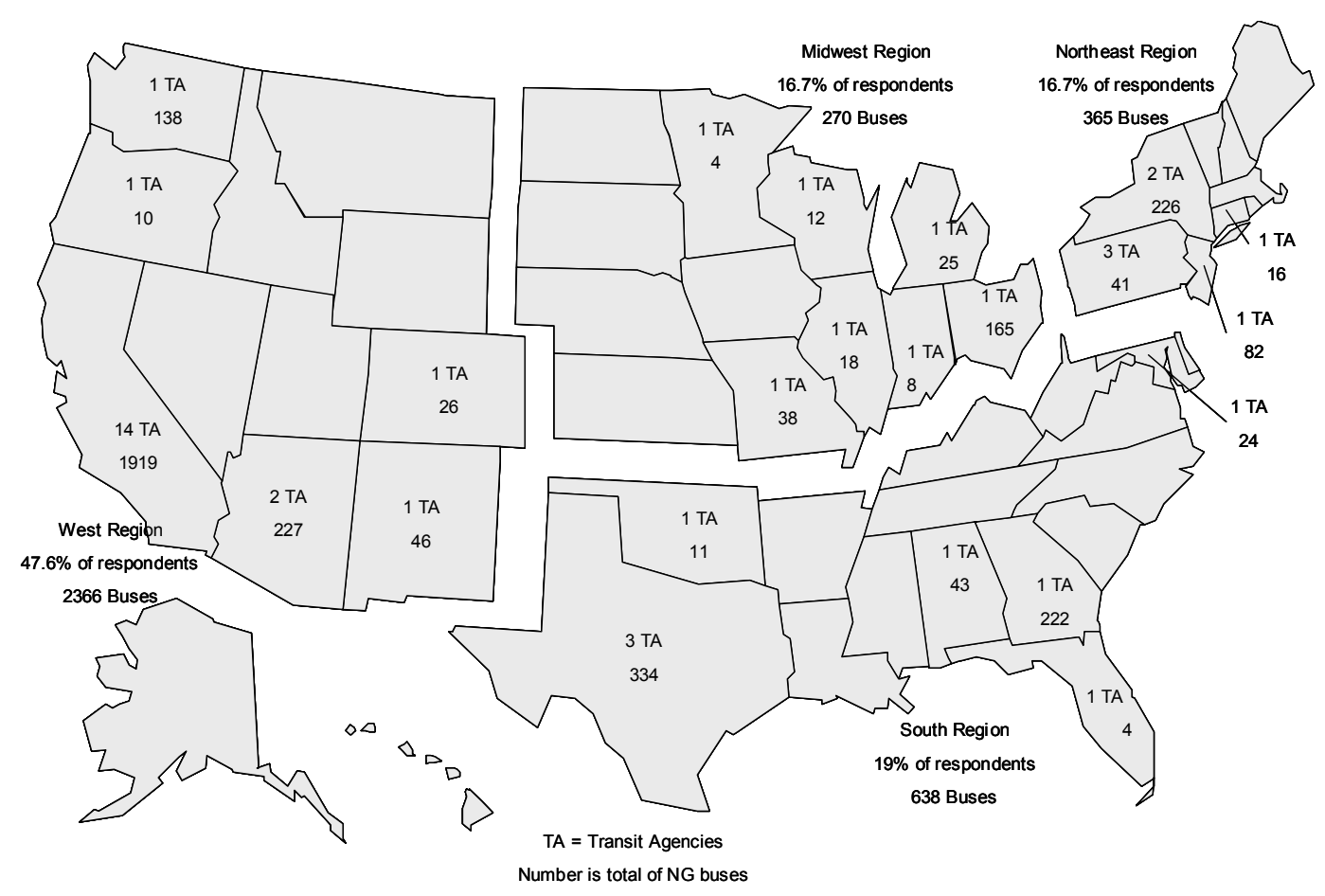

Figure 2. Number of Respondents Currently Operating Natural Gas Buses by State and Census Region

Several interesting conclusions can be drawn from the demographic information collected for the study. One is that the use of natural gas buses in transit applications is not limited to a particular area of the country. Although the western region has the highest percentage of natural gas buses, their use in other areas is growing. Also, $62 \%$ of the agencies interviewed are located in EPA nonattainment areas for one or more criteria pollutants, with ozone being the most prominent. Fifty percent of the fleets are in areas ranked as serious or worse for ozone.

\section{Distribution of Fleets by Size}

The agencies represented in the survey ranged from a very small fleet of six buses to the largest fleet in the country, with more than 4,500 buses. Figure 3 shows the number by fleet size. Fifty percent of the respondents represent fleets of 100 or fewer total buses. Also of interest is the percentage of each fleet that is made up of natural gas buses. Figure 4 lists the number of fleets according to the percentage of natural gas buses in their fleet. They range from a fleet that is only $1.4 \%$ natural gas to one fleet that is $100 \%$ natural gas. The largest group of fleets surveyed (53\%) have a natural gas bus fleet that is $25 \%$ or less of their total fleet. The average was $30.7 \%$ natural gas. 


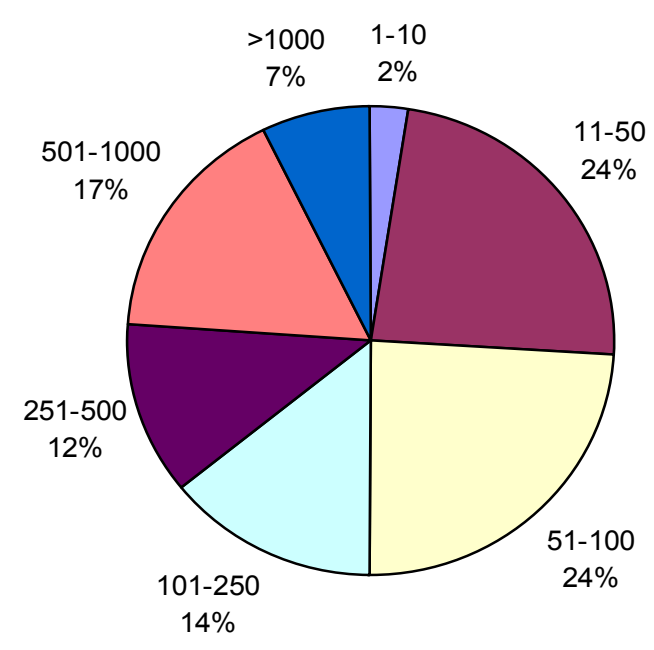

Figure 3. Fleet Size Distribution

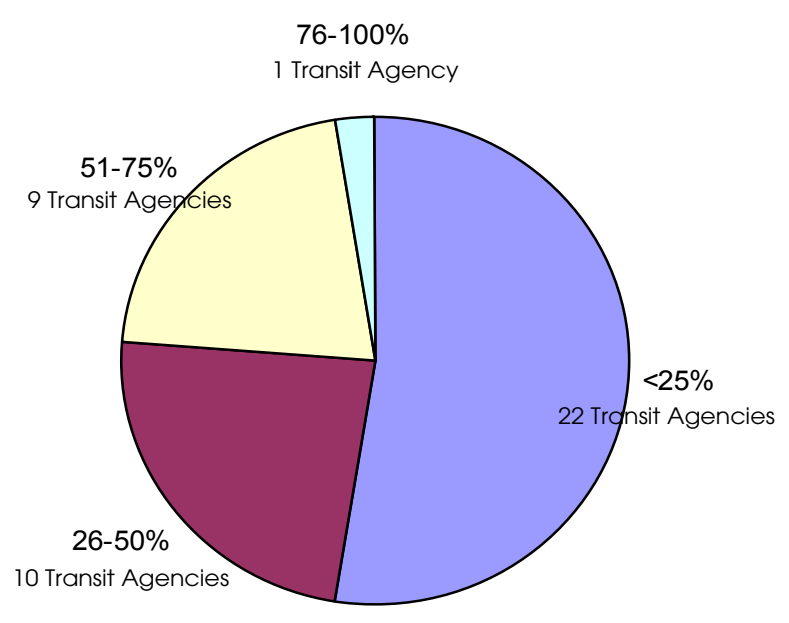

Figure 4. Percentage of Natural Gas Buses in Fleets

In addition to operating natural gas buses, $40.5 \%$ of the respondents reported also using natural gas in their fleet of support vehicles. These support vehicles include cars, pick-ups, and vans, as well as yard equipment such as tugs and forklifts (approximately 440 vehicles total). One fleet reported using 250 natural gas powered support vehicles. This is a significant trend that should be emphasized with good reason. If the transit agency has already invested in fueling equipment and modifying their facilities to accommodate natural gas, then operating a support vehicle fleet on natural gas at the same site is considerably more cost effective and beneficial (compared to a stand-alone alternative fuel operation for support vehicles).

\section{Natural Gas Vehicles Represented by the Survey}

The majority of natural gas buses represented by the survey were full-size transit buses. Nearly $89 \%$ of the fleet managers reported operating 40 -foot natural gas buses. The majority of these buses ranged from model year 1990 to 2001, and almost 59\% were 1998 or newer models. Natural gas engines produced by Detroit Diesel Corporation powered 52\% of the natural gas buses, while $46.5 \%$ were powered by Cummins Engine Company engines. Although John Deere engines powered only $0.4 \%$ of the total natural gas buses, several transit managers reported that they were in the process of repowering some of their fleet with engines from this manufacturer. Table 4 shows the engine manufacturers represented in the survey. Specific engine models are listed in Table 5.

Table 4. Engine Manufacturer

\begin{tabular}{|l|c|c|}
\hline Manufacturer & Total for each OEM & $\begin{array}{c}\text { Percent of total Number of } \\
\text { engines }\end{array}$ \\
\hline Cummins & 1,693 & 46.5 \\
\hline Detroit Diesel & 1,894 & 52.0 \\
\hline John Deere & 15 & 0.4 \\
\hline Other & 40 & 1.1 \\
\hline Total Number of Engines & $\mathbf{3 , 6 4 2}$ & $\mathbf{1 0 0} \%$ \\
\hline
\end{tabular}


Table 5. Most Common Natural Gas Engine Models

\begin{tabular}{|l|c|c|c||}
\hline \hline Manufacturer & Model & $\begin{array}{c}\text { Total for each } \\
\text { Model }\end{array}$ & $\begin{array}{c}\text { Percent of Total } \\
\text { Number of engines }\end{array}$ \\
\hline Cummins & $8.3 G$ & 325 & 8.9 \\
\hline Cummins & L10G $^{*}$ & 1,174 & 32.2 \\
\hline Detroit Diesel & Series 50G & 1,817 & 49.9 \\
\hline
\end{tabular}

${ }^{*}$ L10 model has been discontinued by manufacturer

\section{Service and Operating Conditions}

Interviewers asked respondents to identify the type of service for which they used their natural gas buses. Approximately $70 \%$ of respondents use their natural gas buses exclusively for local service, $14 \%$ use them for express service only, and nearly $16 \%$ use their natural gas buses in both express and local service. We also asked the participants if there were any special conditions that might adversely affect the operation of the natural gas buses in their fleet. Twenty-five fleets $(59.5 \%)$ reported conditions in their area that could have an affect on bus operation. The most common condition reported was high temperature. Figure 5 shows the conditions mentioned and number of responses for each. Some respondents reported multiple conditions in their area.

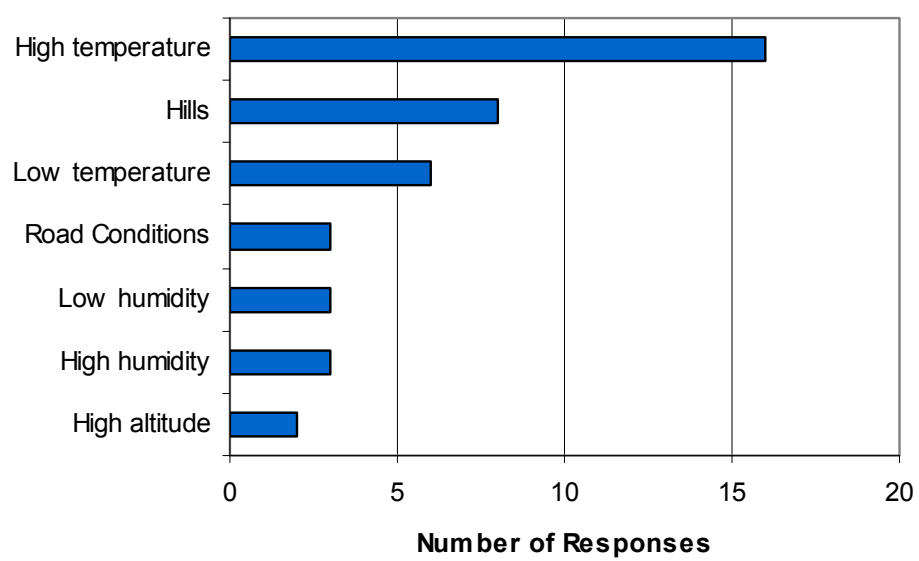

Figure 5. Special Conditions That Affect Bus Operation

\section{Experience with Natural Gas}

"We have had no failures, only success, and we are extremely satisfied."

"To be completely honest, I think the natural gas buses are more trouble than they are worth."

"Now that some of the reoccurring problems have been flushed out, we are realizing the natural gas buses work overall just as well as the diesels."

"The natural gas buses require a lot of maintenance; they're not as reliable and they cost more to operate."

These are just a few of the varied comments we heard from the transit fleets surveyed for the study. Several documents have been published that describe steps to success for natural gas in transit, basing their results on the experiences of a small number of fleets. We wanted to expand on this by including a broader sample of fleets using natural gas buses. To determine just what makes one fleet's experience good while another's is difficult, we categorized the fleets into two groups: "Successes" or "Challenges." We used each fleet's responses to the questionnaire to determine which category a fleet fell into. If the majority of responses were very positive about their experience, they were considered an overall Success. 
If the responses were mostly negative, they were placed into the Challenge category. We wanted to determine if there were any patterns in the responses of a large sample of fleets based on which category they were placed into.

Of the 42 fleets that currently use natural gas buses, $57 \%$ fell into the overall Success category while slightly more than $42 \%$ were considered an overall Challenge. Analysis of the data reveals some interesting insights into what it takes to make a natural gas bus program successful. Roughly half of the fleets whose experience up until now would be considered challenging have learned from their experiences and are continuing to move ahead with their natural gas bus acquisitions. Consequently, there are lessons to be learned from all the fleets. Table 6 shows some of the responses to our survey broken down by group.

As a part of the analysis, we tallied all the comments made about natural gas buses and their operations: both the positive and negative. Table 7 lists the responses by how often they were mentioned by the survey participants. When looking at these comments overall, fleets from each category had both positive and negative comments about their experience. More than half of the fleets surveyed reported that they had experienced successes with natural gas. The majority of these, as expected, fell into the Success category. On the negative side, five of the fleet managers surveyed reported that they had achieved no success with their natural gas buses. It is not surprising that all of these fleets fell into the Challenge group.

Table 6. Responses by Group

\begin{tabular}{||l|c|c|c|c|c||}
\hline \hline \multirow{2}{*}{} & \multicolumn{2}{|c|}{ Success Fleets } & \multicolumn{2}{c|}{ Challenge Fleets } & Overall \\
\cline { 2 - 6 } & Number & Percent & Number & Percent & Number \\
\hline Respondents & 24 & 57 & 18 & 43 & 42 \\
\hline Fleets with 10 or fewer natural gas buses & 2 & 20 & 8 & 80 & 10 \\
\hline Fleets with less than 20\% natural gas & 4 & 24 & 13 & 76 & 17 \\
\hline Fleets reporting that training is minimal & 3 & 43 & 4 & 57 & 7 \\
\hline $\begin{array}{l}\text { Fleets reporting no promotion of natural gas } \\
\text { buses }\end{array}$ & 5 & 50 & 5 & 50 & 10 \\
\hline $\begin{array}{l}\text { Fleets reporting promotion by signs/color on } \\
\text { bus }\end{array}$ & 17 & 63 & 10 & 37 & 27 \\
\hline Fleets reporting major PR for buses & 8 & 89 & 1 & 11 & 9 \\
\hline Fleets fueling off-site & 1 & 14 & 6 & 86 & 7 \\
\hline
\end{tabular}

Table 7. Fleet Experience by Group

\begin{tabular}{||l|c|c|c|c|c||}
\hline \multirow{2}{*}{} & \multicolumn{2}{|c|}{ Success Fleets } & \multicolumn{2}{c|}{ Challenge Fleets } & Overall \\
\cline { 2 - 6 } & Number & Percent & Number & Percent & Number \\
\hline Successes mentioned & 24 & 86 & 4 & 14 & 28 \\
\hline More expensive & 4 & 33 & 8 & 67 & 12 \\
\hline Clean (emissions) & 7 & 64 & 4 & 36 & 11 \\
\hline Training is essential & 7 & 64 & 4 & 36 & 11 \\
\hline Takes commitment & 10 & 91 & 1 & 9 & 11 \\
\hline More maintenance is required & 2 & 25 & 6 & 75 & 8 \\
\hline Good public relations & 6 & 86 & 1 & 14 & 7 \\
\hline Fueling problems & 2 & 29 & 5 & 71 & 7 \\
\hline Similar to diesel buses & 6 & 100 & 0 & 0 & 6 \\
\hline No success with natural gas & 0 & 0 & 5 & 100 & 5 \\
\hline Less reliable & 2 & 50 & 2 & 50 & 4 \\
\hline Reliable & 3 & 100 & 0 & 0 & 3 \\
\hline Range limitations & 2 & 67 & 1 & 33 & 3 \\
\hline
\end{tabular}




\section{Fleet Size}

Based on the information provided in the study, there appears to be an "economy of scale" principle in effect. There were 10 fleets operating 10 or fewer natural gas buses, and $80 \%$ of these small natural gas fleets fell into the Challenge category. Only $20 \%$ of the small natural gas fleets fell into the Success group. Several of the respondents in the Challenge group attributed their difficulties to the low number of buses. One fleet manager stated "We don't have a negative attitude toward CNG at all. If we only had a few diesel buses we would have problems [with them] until we learned all of the fixes." Another agency noted that, because of their low number of natural gas buses, its maintenance staff was not very familiar with them. In addition, it might be difficult for a small fleet to justify an extensive training program for only a few vehicles.

Another way of looking at the size issue is to consider what percent of the total bus fleet is made up of natural gas buses. Of the fleets represented by the study, the percentage of natural gas buses ranged from a low of $1.4 \%$ to a high of $100 \%$. Slightly more than $40 \%$ of the respondents reported natural gas percentages of less than $20 \%$ in their fleets. Most of the low natural gas percentage fleets $(76 \%)$ were considered Challenge fleets. Fleets with the highest percentages of natural gas often mentioned commitment as a reason for their successful natural gas program. Eleven fleet managers responded that it took commitment to make the programs work. The majority of these committed fleets had more than $45 \%$ natural gas and all but one were part of the Success group.

\section{Training}

The majority (78\%) of fleets questioned reported some level of training from basic fueling procedures and natural gas safety to extensive courses on natural gas systems. Only $16.7 \%$ of fleet managers reported minimal training for their personnel. Types of training reported by the fleets are listed in Table 8 . Nearly half the fleets $(45 \%)$ reported that the bus or engine OEM provided training to their employees. Thirtythree percent of fleet managers surveyed said their mechanics received special training to familiarize them with natural gas engines and fuel systems. Safety related training was mentioned by $29 \%$ of fleet managers and another $24 \%$ mentioned extensive coursework taking 40 or more hours. Twenty-six percent of the survey respondents reported that training was important. More than half of those were fleets that were in the Success group.

Table 8. Specific Training

\begin{tabular}{||l|c|c||}
\hline \multicolumn{1}{|c|}{ Type } & Number & $\begin{array}{c}\text { Percent } \\
\text { total }\end{array}$ \\
\hline By bus or engine OEM & 19 & 45 \\
\hline Engine/fuel system & 14 & 33 \\
\hline Safety for natural gas & 12 & 29 \\
\hline Extensive course (40+ hrs) & 10 & 24 \\
\hline Fueling procedures & 5 & 12 \\
\hline
\end{tabular}

\section{Fueling Infrastructure}

Transit agencies have several options for adding natural gas fueling infrastructure to their sites. Some agencies hire an engineer to design and a contractor to build the station, which the agency then owns and operates. The transit agency has complete control over the station, but incurs all capital costs and is responsible for maintaining and operating the station. 
Transit System Ownership

Advantages

- Ownership of the station gives the agency

Disadvantages

complete control

- Up-front capital costs

- lower total cost if project and station are efficiently - Responsible for maintenance and operation managed

Another option is a public/private partnership with a fuel provider. In this option, the agency contracts with a firm to design, build, and maintain the on-site station. The agency usually enters into a long-term contract with the firm to provide fuel and maintain the station. The advantages and disadvantages of this type of relationship are:

$\underline{\text { Public/Private Partnership }}$

Advantages

- No/low up-front capital costs

Disadvantages

- Maintenance is covered

- Possible issues with proprietary technology

- Can provide a stable fuel price through a long-

- Performance risk of provider

term contract

- Potentially more expensive overall than

- Experience of provider

ownership

- Continuing upgrades to facility

Each agency has to weigh the pluses and minuses and choose the best option for its particular organization.

We asked the transit managers several questions about how they fueled their natural gas buses. Results of the survey show that a majority of transit fleets fuel on-site. Eighty-three percent of respondents reported on-site fueling, and $66 \%$ of those fleets own and operate the station. Half of the remaining on-site stations are owned and operated by the local fuel provider. Of the fleets that fuel off-site, all were smaller fleets none of them have more than 20 natural gas buses. Two of these fleets are planning to add on-site infrastructure, and the remainder use local stations.

As expected, analysis of the results shows that installing a good fueling station on-site is instrumental to successfully integrating natural gas buses into a fleet. Of the fleets surveyed, only seven fuel their natural gas buses off-site. It is interesting to note that six of the seven were Challenge fleets. Half of the fleets in the Challenge category listed fuel availability or problems with fueling as reasons for difficulties. The one Success fleet that fuels off-site is in the process of adding a fueling site.

When asked about their decision to add a fueling station to their site, $22 \%$ of respondents said the high number of natural gas vehicles in their fleet was the main driver. Other reasons include convenience, no other option available, and need for control (13\% each). Twenty-six percent did not give a reason for adding fueling infrastructure.

The cost of adding natural gas fueling infrastructure depends on many variables:

- Availability of public/private partnerships

- Type of station: direct fast fill, slow fill, fast fill from storage

- Accessibility of a gas line and available pressure

- Flow rate desired: depending on number of buses and desired fill speed

- Amount of drying or filtering of gas supply needed, and

- Number of compressors: redundancy to prepare for scheduled maintenance or a possible pump failure. 
All of these variables factor into the total cost of the station. Transit Cooperative Research Program (TCRP) Report 38: "Guidebook for Evaluating, Selecting, and Implementing Fuel Choices for Transit Bus Operations" (1998) lists the fueling options for CNG and LNG, as well as other alternative fuels. The report gives a rule of thumb of $\$ 800$ to $\$ 1,000$ for each scf/min capacity when estimating the capital cost of a typical CNG compressor station. A $2000 \mathrm{scf} / \mathrm{min}$ capacity station, for example, would range between $\$ 1.6$ million and \$2 million. A public/private partnership can help defray this up-front cost. There are several fuel providers available for this type of partnership (see Appendix C for a list of providers). More transit agencies are using this type of relationship as a way to help add on-site infrastructure. Contracts with a fuel provider are usually long-term; typically for 10 years. Therefore, it is imperative that this relationship is well defined contractually and that both parties work to keep the relationship productive.

We also asked fleet managers to provide cost information on their fueling stations. Of the 42 respondents, 26 gave an estimated cost for their fueling facility. The costs ranged from a low of $\$ 60,000$, for a 10 -yearold facility servicing 11 natural gas buses, to a high of $\$ 16$ million, for fueling and maintenance facilities for a fleet of more than 80 natural gas buses. The average cost for the respondents was approximately $\$ 2.5$ million. Because of the extreme variability of the data and the lack of specifics on each facility, no direct conclusions about the respondent's station costs can be made.

Like fueling stations, costs to modify existing maintenance facilities for natural gas buses can vary greatly, depending on square footage. Typical modification costs range from $\$ 100,000$ to $\$ 10$ million. The age of the facility is one aspect that can increase cost. For instance, an older building may not be ADA compliant or could contain asbestos that must be removed to complete the upgrades. Contracts to modify facilities often include ventilation upgrades to current OSHA levels, lighting improvements, replacement of worn out HVAC equipment, or other requirements to make the building compliant with codes. The upgrades required for CNG usually result in a facility with better indoor air quality and lighting, making it a better place for workers. Climate is another factor to consider when planning facility modifications. For example, transit agencies in colder climates have to house the buses indoors. Or, because bus depots in crowded cities often have small footprints, they may be multi-storied.

Another question posed to the participants was about their experiences operating the natural gas fueling station. A large group of respondents $(26 \%)$ gave no reply to this question. Twenty-two percent responded that they had experienced no problems with operating their station. Other managers (26\%) reported various problems including gas leaks, difficulties with maintenance contractors, oil carryover, and high maintenance costs.

\section{Public Relations/Promotion}

Many transit agencies using alternative fuels in their fleets reported a positive response from the public. We asked respondents whether they promoted their natural gas buses and what methods they used. The majority $(76 \%)$ of fleet managers reported that their agencies did indeed promote their use of natural gas to the public. Most of those (64\%) responded that they advertised on the buses themselves. This varied from minimal signage (just the blue diamond on the rear), to different paint schemes and logos to differentiate the natural gas buses from the rest of the fleet. Several fleets $(21 \%)$ also issued press releases to advertise the ordering or delivery of new natural gas buses. Other methods of promotion included local media, billboards, brochures, and agency Web sites. One transit manager remarked, "[The natural gas bus] is a public relations benefit, and we try to make some kind of hurrah out of it." The majority of fleets reporting major public relations campaigns were from the Success category.

Many respondents reported good public acceptance of the natural gas buses for several reasons, most involving air quality issues. Most of these were fleets in the Success group. Comments from the survey participants included: "The public care about the environment and feel like they are making an effort [by riding the natural gas bus]" and "it was a success because people perceived us as part of the solution." 


\section{Cost}

Transit agencies receive capital funds from multiple sources. According to APTA's "2001 Public Transportation Fact Book," $\$ 9$ billion in capital funds were received by transit agencies for bus related projects from all sources in 1999. Of these funds, $44.1 \%$ came from the Federal government, $10.2 \%$ from state governments, $12.6 \%$ from local governments, and $33.1 \%$ was raised by the agencies from other sources. When asked if they had received funds for the purchase of their natural gas buses, slightly more than $90 \%$ of the transit managers reported that they had. Approximately $24 \%$ specifically listed Federal Transit Administration funds, and 43\% mentioned other funding sources including the Congestion Mitigation \& Air Quality Improvement Program (CMAQ), the South Coast Air Quality Management District (SCAQMD), and the local fuel providers. Several agencies also reported receiving funds to help build their natural gas fueling infrastructure.

The majority of fleets reported that the natural gas buses cost more to purchase. Although the purchase cost of natural gas buses is higher than diesel, this increment appears to be dropping. According to the "TCRP Report 38," the incremental cost for a 40-foot natural gas transit bus in 1998 cost between $\$ 65,000$ to $\$ 75,000$. Data collected for APTA's 2001 Vehicle Database show the average cost for a 40foot diesel powered transit bus is $\$ 271,700$, while a comparable natural gas bus averages $\$ 317,400$. This gives an incremental cost of approximately $\$ 46,000$. (This is based on data reported to APTA by transit agencies on a yearly basis. APTA estimates that approximately $70 \%$ of all buses are represented by the agencies that report.)

The second most common comment from the fleets was that the operating costs were higher for natural gas than for diesel. Nearly $29 \%$ of the respondents reported overall costs of the natural gas buses as a hurdle to overcome. Although most of these responses ( 8 of 12) came from the Challenge group, several of the Success fleets also stated that thoroughly understanding the costs involved went a long way toward recognizing opportunities for savings and making their operations a success. For example, it is often stated that natural gas engines require fewer oil and filter changes than diesel engines (sometimes extended to 12,000 miles or more), resulting in reduced maintenance costs in labor and materials. In fact, results from regular oil tests convinced one fleet manager we interviewed to increase the number of miles between oil changes in his natural gas buses. Additionally, two of the fleet managers questioned responded that the natural gas buses actually cost less than diesel to operate. One manager remarked that the natural gas buses in his fleet had a lower cost per mile than the diesel buses, although he had not originally expected that to be the case. The other manager remarked that his fuel cost for natural gas was quite low compared to diesel.

Why the variation in reported operating costs for natural gas buses? One obvious issue is fuel cost, which varies by region. Fuel-purchasing savvy can also result in significant cost savings. Recent deregulation within the natural gas industry now makes it possible for most transit properties to negotiate for long term prices and seasonal bulk purchases at prices well below what they would pay by simply purchasing direct from a local utility. Most transits have been following a similar practice with diesel fuel for years, but only a small number are now doing this with natural gas. Those that do report not only significant savings but pricing stability that doesn't fluctuate with closely linked weather-sensitive commodities like fuel oil for home heating (No.2 diesel).

Another variable to overall costs is vehicle maintenance and operation practices. Many successful fleets have invested in extensive training programs for their maintenance personnel. Knowledgeable technicians can take less time to diagnose and repair vehicles, minimizing labor charges and downtime of buses. Tried and true daily operations for diesel buses may need to be "unlearned" or modified in order to realize the savings potential of their natural gas counterparts. For example, during subfreezing weather it is a common practice to start diesel buses and let them idle through the night to avoid morning cold-start problems due to thickened or water contaminated diesel fuel. As a gaseous fuel, natural gas buses are not subject to these cold start conditions. Yet a number of agencies continue to practice cold weather idle 
procedures even for their natural gas buses. This is an unrealized savings/waste that is usually unaccounted for. Many cost factors are often missed because data collection practices are not uniform and complete at each agency. While some transit agencies have large databases with each maintenance action recorded in detail, others have records that are spotty at best. These poor data collection methods can result in inaccurate reports of costs/savings.

\section{Critical Practices for Success}

During the phone interview, we asked fleet managers, "What is the one thing critical to a successful natural gas bus program?" Figure 6 shows the responses. Table 9 gives the responses by group and overall. The most common response was that training, especially of maintenance personnel, was essential for success. Not surprisingly, the majority (10 of 14) of managers with this opinion fell into the Success category. Two of the fleet managers report taking a proactive approach toward maintaining their natural gas buses by requiring that their mechanics complete extensive training courses on the buses and natural gas systems.

Adequate fueling was also cited as critical for success. Of the fleets giving this advice, two had no on-site fueling, one had slow-fill fueling, and the remaining fleets had experienced some difficulties in adding infrastructure. "Plan ahead," one fleet manager cautioned. Because the original station located at his agency was designed for a small number of buses, they had to make major modifications to their station when they purchased additional natural gas buses.

Commitment to natural gas program was mentioned by nearly $12 \%$ of respondents. The majority of those fleets (4 of 5) were from the Success group. One manager commented, "[You need] dedication and commitment to the program; you can't start running at the first sign of trouble." Another manager noted that commitment must include all project partners. He remarked, "[The engine OEM] really worked with us in the beginning, so the whole process was not that difficult."

Also listed as critical for success was a thorough understanding of the costs involved and the opportunities for savings that may come with modifying age-old diesel practices that may now be unnecessarily burdening natural gas operations. Some fleets reported cost savings for fuel or lower maintenance costs, but the majority of fleets participating in the survey reported higher costs for the natural gas buses. A fleet that is aware of the possible increases in operational costs can be prepared to offset the difference in some way. Other fleet managers mentioned that the natural gas buses must have good performance - in other words, comparable to the standard diesel bus.

Table 9. Critical for Success by Group

\begin{tabular}{||l|c|c|c|c|c||}
\hline \multirow{2}{*}{ | } & \multicolumn{2}{|c|}{ Success Fleets } & Challenge Fleets & Overall \\
\cline { 2 - 6 } & Number & Percent & Number & Percent & Number \\
\hline Training & 10 & 71 & 4 & 29 & 14 \\
\hline Adequate fueling & 2 & 40 & 3 & 60 & 5 \\
\hline Commitment & 4 & 80 & 1 & 20 & 5 \\
\hline Understanding cost & 3 & 75 & 1 & 25 & 4 \\
\hline Good performance (for natural gas buses) & 1 & 25 & 3 & 75 & 4 \\
\hline Other & 2 & 50 & 2 & 50 & 4 \\
\hline Environmental (emissions) & 2 & 67 & 1 & 33 & 3 \\
\hline No answer & 0 & 0 & 3 & 100 & 3 \\
\hline
\end{tabular}




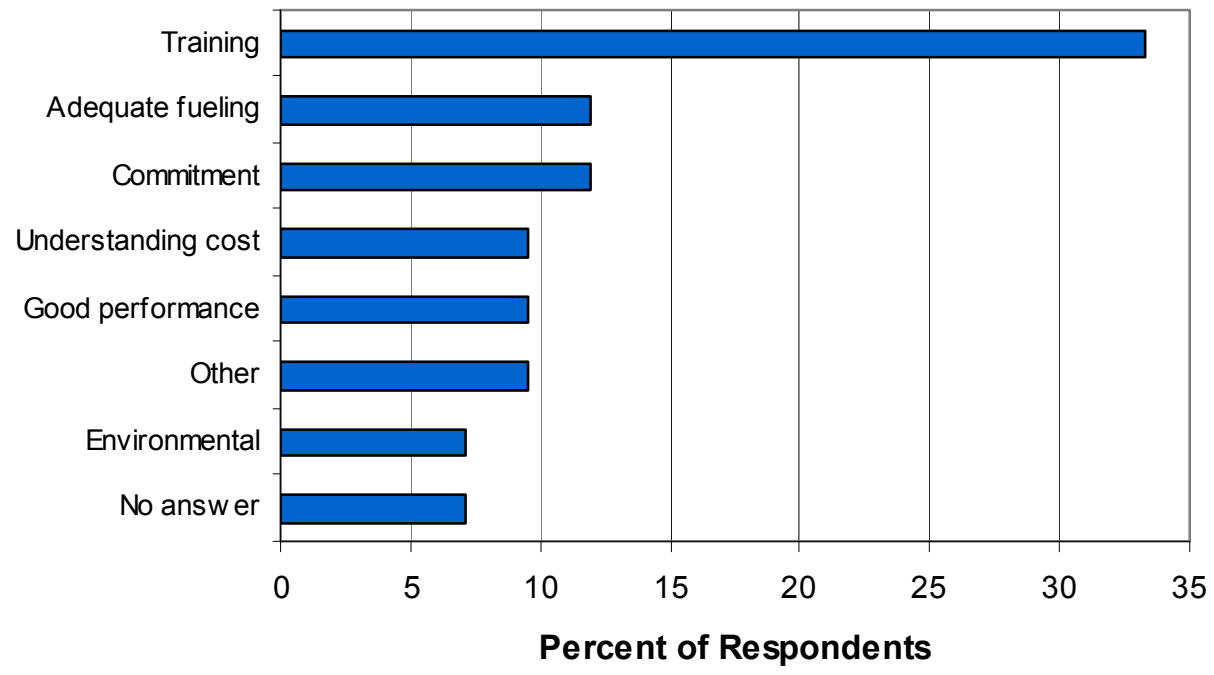

Figure 6. What is critical for success?

\section{Future Plans}

We asked respondents about their agency's future plans with respect to vehicle purchases. Table 10 lists their responses. Of the 42 fleets surveyed, $69 \%$ have ordered or plan to purchase additional natural gas buses. The majority of those fleets (21 of 30) fell into the Success category. Eleven of the fleets surveyed plan to take it a step further by converting their entire operation to natural gas. Sixty-four percent of those fleets were from the Success group, while 36\% were from the Challenge group. It is interesting to note that despite having difficulties integrating natural gas into their operations, half of the Challenge fleets still plan to purchase additional natural gas buses. A likely reason for this is to help meet air quality standards. Of the 42 fleets surveyed, $57 \%$ are located in areas that are in nonattainment for ozone, $23 \%$ for carbon monoxide, and 36\% for particulate matter. Many also cite positive public awareness and community support for their natural gas bus programs as a reason for their continued commitment.

Table 10. Future plans by Group

\begin{tabular}{||l|c|c|c|c|c||}
\hline \hline \multirow{2}{*}{ Future Plans } & \multicolumn{2}{|c|}{ Success Fleets } & Challenge Fleets & Overall \\
\cline { 2 - 6 } & Number & Percent & Number & Percent & Number \\
\hline Fleets planning more CNG/LNG purchases & 21 & 70 & 9 & 30 & 29 \\
\hline Fleets planning to be 100\% CNG/LNG & 7 & 64 & 4 & 36 & 11 \\
\hline Fleets considering hybrid buses & 3 & 38 & 5 & 63 & 8 \\
\hline Fleets considering fuel cell buses & 6 & 75 & 2 & 25 & 8 \\
\hline
\end{tabular}

Many of the fleet managers interviewed also reported an interest in newer technologies such as hybrid electric and fuel cell propulsion. Although an equal number of fleets mentioned these two technology options, more of the Challenge fleets expressed interest in the hybrids, while most of the interest in fuel cell buses came from the Success group (perhaps because natural gas is frequently used as a feedstock fuel to produce the hydrogen for fuel-cell systems, and gaseous hydrogen vehicle technologies are similar to $\mathrm{CNG}$ ). Several fleets also mentioned interest in cleaner diesel technology. For fleets considering advanced technology buses, the lessons learned from the experiences of fleets with natural gas will surely apply to adoption of any new technologies. 


\section{Why did they Choose Natural Gas?}

Why does a transit agency choose to add natural gas buses to their fleet? This decision is most often made at the upper levels of management in each agency. To determine the reasons for choosing natural gas, we interviewed high-level managers from a select group of agencies. We asked two basic questions:

- Why did your agency choose natural gas?

- "Do you consider your program a success and why?

The reasons given for choosing natural gas fell into two categories: environmental or political. Although several agencies questioned for our survey are located within the South Coast Air Quality Management District, where purchase of natural gas buses is regulated, only one of those fleets gave this regulation as the main reason for their switch to alternative fuels. The majority (72\%) of high-level managers interviewed responded that their decision to go with natural gas was for environmental reasons. Many of the agencies are located in areas that are in nonattainment for one or more criteria pollutants, therefore air quality was of great importance.

Several managers also reported a favorable public response to their choice. One manager remarked, "The natural gas buses were well received by the community and our passengers, so we continued on the path of a complete natural gas fleet." The remainder of high-level managers reported having political reasons for choosing natural gas. Many of those fleets decided to purchase natural gas buses at the urging of their local air pollution district. Some also reported that the funding available to offset the incremental cost of alternative fuel buses and to add fueling infrastructure was a consideration.

When asked about their agency's experience with natural gas, the majority of high-level managers $(60 \%)$ felt that their programs were successful. Another 32\% felt that their experience with natural gas technology was mixed, while only $8 \%$ felt their programs were not successful. Of the high-level managers responding "yes" when asked if their programs were a success, $67 \%$ gave environmental reasons for that success, mostly because of air quality improvements and the favorable public response. The managers with mixed results also cited environmental benefits as the positive results, but the higher cost their fleets experienced with natural gas tempered their response. Only two high-level managers believed that their natural gas program was not a success. One listed the high cost as the main reason, but both managers mentioned the poor performance of their particular natural gas buses compared to similar diesel buses in their fleet. 


\section{Lessons Learned}

By interviewing 42 fleets about their natural gas vehicle successes and challenges, NREL was able to identify several "lessons learned" that were common to the agencies that successfully integrated natural gas vehicles into their fleets.

- Do your homework. Investigate the different options for fueling and maintaining natural gas buses and determine what is cost effective for your agency. What works well in one area may not be effective in others. Get advice from those who have had a good experience, duplicate the successes and avoid/address the challenges up front so that there are no surprises. Appendix C lists various resources for fleets interested in adding natural gas buses to their operations.

- Assemble a team. Don't try to do it alone. Look for experienced partners to aid in planning, troubleshooting, and optimizing vehicles and infrastructure. Include local officials from the early stages of planning to avoid trouble down the line. This includes fire marshals, regulators, and politicians.

- Be committed at all levels of the organization. It takes the dedication of all staff, from corporate managers to drivers and mechanics. Be prepared to provide resources, including knowledgeable personnel, time, and funding.

- Understand the possible costs involved. Know the up-front costs to adding natural gas buses and infrastructure and budget accordingly.

- Plan a comprehensive training program. Integrating a new technology takes persistence and patience. Maintenance workers need to be familiar with the new technology in order to troubleshoot and repair problems. This takes a thorough training program. Work with OEM or other partners to build a training program.

- Install adequate fueling infrastructure. Ensure an adequate fuel supply by planning the station according to the specific needs of the fleet. This requires an understanding of the duty-cycle requirements. Don't forget to take potential growth of the natural gas fleet into account. Look into the different options of how to purchase your fuel. Work with an experienced gas broker or take time to develop natural gas purchasing savvy within your organization so that you can recognize market trends and negotiate for optimal long-term fuel pricing.

- Promote the program to the public. Take advantage of the public relations benefit of operating vehicles that pollute less. A good image in the public eye can lead to increased ridership and revenue.

A fleet must also define what success means to their particular agency. The potential for overall success in the program should be judged on how well these goals are met. If a fleet follows these guidelines, experience shows that transit agencies can be successful with natural gas, providing benefits to their region of improved air quality and energy security. 


\section{Acknowledgements}

This work was sponsored by the Office of Technology Utilization, which is part of the U.S. Department of Energy's Office of Transportation Technologies in Washington, D.C. Mr. Lee Slezak is DOE's program manager for the Field Operations Program. Appreciation is expressed to RP Publishing in Denver, Colo., for their help in developing the questionnaire and for collecting the data and to Kevin Chandler of Battelle for his continued support of the program. A special thanks is also extended to all the

fleet managers and other transit agency personnel for providing information on their operations as well as their thoughts and opinions.

\section{References}

1. APTA 2001 Public Transportation Fact Book, 52 ${ }^{\text {nd }}$ edition, March 2001.

2. APTA 2001 Vehicle Database, June 2001.

3. "Guidebook for Evaluating, Selecting, and Implementing Fuel Choices for Transit Bus Operations," Transit Cooperative Research Program Report 38, National Academy Press, Washington, DC, 1998.

4. Feedback and comments expressed by transit agency management and maintenance personnel at the Natural Gas Transit User's Group meetings sponsored by DOE and the Gas Technology Institute (Atlanta, GA. - January 2001, Thousand Palms, CA. - November 2001), DOE-HQ contact Dennis Smith.

\section{Other Related Publications}

Battelle, 1996, "Alternative Fuel Transit Buses, The Pierce Transit Success Story," National Renewable Energy Laboratory, Golden, CO, NREL/SP-425-21606.

Chandler, K., Norton, P., Clark, N., 2000, "Dallas Area Rapid Transit's (DART) LNG Bus Fleet: Final Results," National Renewable Energy Laboratory, Golden, CO NREL/BR-540-28739.

Chandler, K., Malcosky, N., Motta, R., Norton, P., Kelly, K., Schumacher, L., Lyons, D., 1996, "Alternative Fuel Transit Bus Evaluation Program Results," SAE International, Warrendale, PA, SAE Pub. \#961082.

Eudy, L., 2000, “SuperShuttle CNG Fleet Evaluation,” National Renewable Energy Laboratory, Golden, CO, NREL/TP-540-29226.

Motta, R., Norton, P., Kelly, K., Chandler, K., Schumacher, L., Clark, N., 1996, “Alternative Fuel Transit Buses, Final Results from the National Renewable Energy Laboratory (NREL) Vehicle Evaluation Program," NREL, Golden, CO, NREL/TP-425-20513. 


\section{Appendix A - Questionnaire}

NREL Natural Gas in Transit Study

April-June 2001

\section{Questionnaire \# 1}

(1) Do you currently operate natural gas buses?

Yes, if yes proceed

_ No, if no go to Section 2 at the end of the survey

(2) How many of your buses use compressed natural gas (CNG) as a fuel source?

LNG? Diesel? Other? Ask what other fuels are used

gasoline methanol propane electric hybrid-electric fuel cell

(3) Do you operate any other types of NG vehicles (other than buses)?

If so, what and how many?

(4) I'd like to ask you several questions about your CNG buses and since I'm organizing the information by type of service your buses are used in. Let me first ask if you have CNG buses that are used in... express service?

local service?

(5) I have several questions that require statistical data on your buses.

Fill in the following table for each type of bus:

\begin{tabular}{|l|l|l|l|}
\hline Fuel used & & & \\
\hline Make of Chassis & & & \\
\hline Number of vehicles & & & \\
\hline Length (ft) & & & \\
\hline Engine Make & & & \\
\hline Engine Model & & & \\
\hline Average years in service & & & \\
\hline Average miles per month & & & \\
\hline Driving Range/tank size(NG) & & & \\
\hline Purchase Price & & & \\
\hline Maintenance cost per month & & & \\
\hline Operating Cost per mi & & & \\
\hline Miles between Road Calls & & & \\
\hline Problems/lssues & & & \\
\hline Resolution & & & \\
\hline
\end{tabular}


(6) Are there any special operating conditions in your area that might affect the performance of your CNG buses such as...

hills

high temperature

low temperature

- high altitude

high humidity

_ road conditions

(7) What kind of special CNG-related training do you give your technicians?

(8) Many transit organizations receive outside funding (i.e. FTA monies, grants, incentives) to assist in the purchase of natural gas buses. Has your organization received this type of funding?

(9) Does your organization promote its natural gas buses through advertising, public relation, signage, etc?

(10) How do you accommodate fueling for your CNG buses? Do you...

a. fuel your natural gas buses on-site?

_

no, if no go to question 12

b. own and operate the natural gas fueling station? yes, if yes proceed

no, if no, who does own and operate the station

c. tell me about the decision to add a natural gas fueling site. More specifically, what were the reasons that led you to make that decision?

(11) Using ballpark figures, please tell me about your on-site fueling station in terms of...

- cost to install

- cost to operate and maintain

- problems associated with owning and operating a natural gas station

(12) Please tell me about your overall experience with natural gas buses. Feel free to mention both the successes and challenges.

(13) You mentioned (cite each of the success issues mentioned in question 12) as a success. In your opinion why was this successful?

(14) If you had to list one factor as being the most critical to the success of a natural gas bus program, what would it be?

(15) What is your long-term plan for alternative fuels? 


\section{For California transit agencies only}

(A) According to my notes the California Air Resources Board had given transit agencies a deadline of January 31 st to choose one of two paths for meeting future transit bus emissions regulation. Did your agency choose...

the alternative fuels path

the diesel path

(B) What were the main factors that lead your organization to that decision?

(C) Was your experience with natural gas buses a factor in this decision?

Y Yes, if yes how so?

$$
\text { No }
$$

\section{Section 2}

If answer "no" to question number one

(I) Have you ever operated natural gas buses in your fleet?

$$
\begin{aligned}
& \text { Yes, if yes proceed } \\
& \text { No, if no go to question IV }
\end{aligned}
$$

(II) Please tell me a little about your experience with natural gas buses.

(III) Why did you stop operating natural gas buses?

(IV) Do you anticipate operating natural gas buses in the future? When?

(V) Looking long-term, say three to five years, do you anticipate operating any advanced technology buses in the future? If yes which type? electric hybrid-electric fuel cells

Questionnaire \#2 - Given to a group of transit managers.

(1) Confirm the numbers and model of each type of NG engine in your fleet.

(2) Have you experienced any specific engine-related problems with your current natural gas-powered equipment that you haven't experience with your diesel engines? If so, (repeat any specific problems mentioned) what steps have been taken to resolve these problems?

(3) (Refer to original survey) What amount, if any, and type of training did your technicians receive from the engine manufacturer? Was this adequate? What type of training would you like to see?

(4) Have you upgraded any of your natural gas engines through rebuilds, repowers or complete engine replacements? If so, which engine(s) and model(s) were originally in use?

Questionnaire \# 3 - Given to high-level managers

(1) Why did you choose to use natural gas buses in your fleet?

(2) Do you think it has been a success, why or why not? 
Appendix B - List of Agencies

\begin{tabular}{|c|c|c|c|}
\hline Organization & City & State & NG buses? \\
\hline Long Beach Transit & Long Beach & $\mathrm{CA}$ & No \\
\hline Delaware Transit Corporation & Wilmington & $\mathrm{DE}$ & No \\
\hline Rock Island, III. & Rock Island & $\mathrm{IL}$ & No \\
\hline Mass Transit Administration & Baltimore & MD & No \\
\hline Liberty Lines Transit & Mount Vernon & NY & No \\
\hline Rochester-Genesee Regional Transportation Authority & Rochester & NY & No \\
\hline Community Action Transit System & Piketon & $\mathrm{OH}$ & No \\
\hline Houston Metro Transit & Houston & $\mathrm{TX}$ & No \\
\hline VIA Metropolitan Transit & San Antonio & TX & No \\
\hline Milwaukee City Transit Systems & Milwaukee & WI & No \\
\hline Sweetwater County Transit Authority & Rock Springs & WY & No \\
\hline Birmingham-Jefferson County Transit Authority & Birmingham & $\mathrm{AL}$ & Yes \\
\hline City of Phoenix Transit System Public Transit Department & Phoenix & AZ & Yes \\
\hline Sun Tran (City of Tucson MTS) & Tucson & $\mathrm{AZ}$ & Yes \\
\hline City of Glendale & Glendale & $\mathrm{CA}$ & Yes \\
\hline Foothill Transit & West Covina & CA & Yes \\
\hline Golden Empire Transit District & Bakersfield & $\mathrm{CA}$ & Yes \\
\hline Kern Regional Transit & Bakersfield & $\mathrm{CA}$ & Yes \\
\hline Los Angeles County Metropolitan Transportation Auth. (LAC MTA) & Los Angeles & CA & Yes \\
\hline Monterey Salinas Transit & Monterey & $\mathrm{CA}$ & Yes \\
\hline Orange County Transportation Auth, (OCTA) & Orange County & $\mathrm{CA}$ & Yes \\
\hline Riverside Transit Agency & Riverside & $\mathrm{CA}$ & Yes \\
\hline Sacramento Regional Transit District & Sacramento & $\mathrm{CA}$ & Yes \\
\hline San Diego Metro Transit Development District & San Diego & $\mathrm{CA}$ & Yes \\
\hline San Luis Obispo Transit & San Luis Obispo & $\mathrm{CA}$ & Yes \\
\hline Sonoma County Transit & Santa Rosa & $\mathrm{CA}$ & Yes \\
\hline SunLine Transit Agency & Thousand Palms & $\mathrm{CA}$ & Yes \\
\hline University Transportation and Parking Services & Sacramento & $\mathrm{CA}$ & Yes \\
\hline Regional Transportation District (RTD) & Denver & $\mathrm{CO}$ & Yes \\
\hline Norwalk Transit District & Norwalk & CT & Yes \\
\hline Pinellas Suncoast Transit Auth. & Clearwater & FL & Yes \\
\hline Metropolitan Atlanta Rapid Transit Auth. (MARTA) & Atlanta & GA & Yes \\
\hline Springfield Mass Transit District & Springfield & $\mathrm{IL}$ & Yes \\
\hline Gary Public Transportation Corp. & Gary & IN & Yes \\
\hline Montgomery County Transit Systems & Rockville & MD & Yes \\
\hline City of Detroit Department of Transportation & Detroit & $\mathrm{Ml}$ & Yes \\
\hline Minnesota Valley Transit Authority & Burnsville & $\mathrm{MN}$ & Yes \\
\hline Bi-State Development Agency & St. Louis & $\mathrm{MO}$ & Yes \\
\hline New Jersey Transit & Newark & $\mathrm{NJ}$ & Yes \\
\hline City of Albuquerque & Albuquerque & NM & Yes \\
\hline Niagara Frontier Transportation Authority & Buffalo & NY & Yes \\
\hline New York City Transit (NYCT) & New York & NY & Yes \\
\hline Greater Cleveland Regional Transit Authority & Cleveland & $\mathrm{OH}$ & Yes \\
\hline Central Oklahoma Transportation \& Parking Authority & Oklahoma City & OK & Yes \\
\hline Salem Area Mass Transit District & Salem & OR & Yes \\
\hline Berks Area Reading Transportation Authority & Reading & $\mathrm{PA}$ & Yes \\
\hline Centre Area Transportation Authority & St. College & $\mathrm{PA}$ & Yes \\
\hline Indiana County Transit Authority & Indiana & PA & Yes \\
\hline Dallas Area Rapid Transit (DART) & Dallas & TX & Yes \\
\hline EI Paso Mass Transit Department & El Paso & TX & Yes \\
\hline Fort Worth Transportation Authority & Fort Worth & $\mathrm{TX}$ & Yes \\
\hline Pierce County Public Transportation Benefit Area Authority Corp. & Tacoma & WA & Yes \\
\hline City of Kenosha, Department of Transportation & Kenosha & WI & Yes \\
\hline Total Fleets Represented & & & 53 \\
\hline Total Using NG buses & & & 42 \\
\hline Percent of the total & & & 79.2 \\
\hline
\end{tabular}


Number of Buses Reported by each Organization by Fuel Type (as of the date of the survey)

\begin{tabular}{|c|c|c|c|c|}
\hline Organization & CNG & LNG & Diesel & Total \\
\hline Birmingham-Jefferson County Transit Authority & 43 & 0 & 49 & 92 \\
\hline City of Phoenix & 0 & 187 & 212 & 399 \\
\hline Sun Tran (City of Tucson MTS) & 40 & 0 & 153 & 193 \\
\hline City of Glendale & 17 & 0 & 11 & 28 \\
\hline Foothill Transit & 5 & 0 & 350 & 355 \\
\hline Golden Empire Transit District & 41 & 0 & 37 & 78 \\
\hline Kern Regional Transit & 9 & 0 & 34 & 43 \\
\hline LAC MTA & 1,318 & 0 & 1,000 & 2,318 \\
\hline Monterey Salinas Transit & 17 & 0 & 75 & 92 \\
\hline OCTA & 0 & 61 & 430 & 491 \\
\hline Riverside Transit Agency & 25 & 0 & 67 & 92 \\
\hline Sacramento Regional Transit District & 152 & 0 & 66 & 218 \\
\hline San Diego Metro Transit Development District & 200 & 0 & 372 & 572 \\
\hline San Luis Obispo Transit & 2 & 0 & 16 & 18 \\
\hline Sonoma County Transit & 24 & 0 & 26 & 50 \\
\hline SunLine Transit Agency & 46 & 0 & 0 & 46 \\
\hline University Transportation and Parking Services & 2 & 0 & 4 & 6 \\
\hline Regional Transportation District & 26 & 0 & 900 & 926 \\
\hline Norwalk Transit District & 16 & 0 & 24 & 40 \\
\hline Pinellas Suncoast Transit Auth. & 4 & 0 & 167 & 171 \\
\hline Metropolitan Atlanta Rapid Transit Auth. & 222 & 0 & 490 & 712 \\
\hline Springfield Mass Transit District & 18 & 0 & 32 & 50 \\
\hline Gary Public Transportation Corp. & 0 & 8 & 28 & 36 \\
\hline Montgomery County Transit Systems & 24 & 0 & 229 & 253 \\
\hline City of Detroit DOT & 25 & 0 & 553 & 578 \\
\hline Minnesota Valley Transit Authority & 4 & 0 & 85 & 89 \\
\hline Bi-State Development Agency & 38 & 0 & 540 & 578 \\
\hline New Jersey Transit & 82 & 0 & 1,000 & 1,082 \\
\hline City of Albuquerque & 46 & 0 & 21 & 67 \\
\hline Niagara Frontier Transportation Authority & 5 & 0 & 350 & 355 \\
\hline NYCT & 221 & 0 & 4,300 & 4,521 \\
\hline Greater Cleveland Regional Transit Authority & 167 & 0 & 800 & 967 \\
\hline Central Oklahoma & 11 & 0 & 68 & 79 \\
\hline Salem Area Mass Transit District & 10 & 0 & 59 & 69 \\
\hline Berks Area Reading Transportation Authority & 12 & 0 & 41 & 53 \\
\hline Centre Area Transportation Authority & 24 & 0 & 11 & 35 \\
\hline Indiana County Transit Authority & 5 & 0 & 10 & 15 \\
\hline DART & 0 & 139 & 650 & 789 \\
\hline El Paso Mass Transit Department & 45 & 35 & 79 & 159 \\
\hline Fort Worth Transportation Authority & 115 & 0 & 98 & 213 \\
\hline Pierce County Public Transportation & 138 & 0 & 69 & 207 \\
\hline City of Kenosha, DOT & 12 & 0 & 40 & 52 \\
\hline
\end{tabular}




\section{Appendix C - Resources}

\section{Natural Gas Bus Manufacturers}

The following information is from the Heavy Vehicle and Engine Resource Guide produced by NREL for the U.S. DOE Office of Transportation Technologies. Download the electronic copy of the document from:

http://www.afdc.doe.gov/pdfs/hvrg.pdf

\section{Blue Bird Corp.}

Phone: 478-822-2262

Web site: http://www.blue-bird.com

Fuels: CNG, LNG

Applications: Transit bus, shuttle

\section{Chance Coach}

Phone: 888-391-1777

Web site: http://www.chancecoach.com

Fuels: CNG

Applications: Trolley, transit bus

\section{Motor Coach Industries}

Phone: 800-7 43-3624

Web site: http://www.mcicoach.com

Fuels: CNG

Applications: Commuter bus

\section{New Flyer of America}

Phone: 204-224-1251

Web site: http://www.newflyer.com

Fuels: CNG, LNG

Applications: Transit bus

\section{Nova Bus Inc.}

Phone: 505-347-2011

Web site: http://www.novabuses.com

Fuels: CNG, LNG

Applications: Transit bus

\author{
Champion Bus \\ Phone: 800-776-4943 \\ Web site: http://www.championbus.com \\ Fuels: CNG \\ Applications: Transit bus, shuttle, paratransit
}

\section{El Dorado National}

Phone: 909-591-9557

Web site: http://www.lasseter.com/eldorado.htm

Fuels: CNG, LNG

Applications: Transit bus, shuttle

\section{Neoplan USA Corp.}

Phone: 719-336-3256

Web site: http://www.neoplanusa.com

Fuels: CNG, LNG

Applications: Transit bus, commuter, shuttle

\author{
North American Bus Industries \\ Phone: 805-529-5080 \\ Web site: http://www.nabiusa.com \\ Fuels: CNG, LNG \\ Applications: Transit bus
}

\section{Omnitrans}

Phone: 405-840-2622

Web site: http://www.cngvehicle.com

Fuels: CNG, LNG

Applications: Transit bus, shuttle

\section{Orion Bus Industries}

Phone: 905-403-1111

Web site: http://www.freightliner.com/products/orion.html

Fuels: CNG

Applications: Transit bus

\section{Fuel Providers}

Source: Advanced Vehicles 2001, RP Publishing, Denver, CO. Web site: www.rppublishing.com

\section{Blue Fuels L.P.}

1340 Post \& Paddock, Suite 300

Grand Prairie, TX 75050

Contact: Stan Taylor

Phone: 972-647-2341 fax: 972-647-2342

E-mail: staylor@bluefuels.com

Web site: www.blue-energy.net

\author{
ENRG (formerly Pickens Fuel Corp.) \\ 3030 Old Ranch Pkwy., \#280 \\ Seal Beach, CA 90740 \\ Contact: Andrew Littlefair \\ Phone: 572-493-2804 \\ fax: 562-493-4532 \\ E-mail: pfc@pickensfuelcorp.com \\ Web site: www.pickensfuel.com
}


The Hanover Company

20602 E. 81st St.

Broken Arrow, OK 74014

Contact: Bill Sayre

Phone: 918-259-2363

Fax: 918-259-2386

Web: www.hanover-co.com

NexGen Fueling (a division of Chart Industries)

3505 Country Rd. 42 W.

Burnsville, MN 55306-0856

Phone: 800-838-0856

Fax: 952-882-5172

Web site: www.nexgenfueling.com

\section{Trillium USA}

136 E. South Temple, Suite 1900

Salt Lake City, UT 84111

Contact: Jan Hull

Phone: 801-531-1166

Fax: 801-521-7692

E-mail: info@trilliumusa.com

Web site: www.trilliumuasa.com
Kingdom Group

121 East 60th St.

New York, NY 10022

Contact: Juliet Burdelski

Phone: 212-605-9999

Fax: 212-605-9995

E-mail: info@thekingdomgroup.com

Web: www.thekingdomgroup.com

Pinnacle CNG Systems LLC

P.O. Box 2499

Midland, TX 79072

Contact: Drew Diggins

Phone: 915-686-7002

Fax: 915-686-1557

E-mail: ddiggins@pinnaclecng.com

Web site: www.pinnaclecng.com

\section{Other Resources}

\section{National Clean Cities Program}

http://www.cities.doe.gov

DOE's National Clean Cities Program was designed to achieve the EPAct goal of accelerating the use of alternative fuel vehicles in the transportation sector. The program supports public-private partnerships that deploy alternative fuel vehicles and builds supporting fueling infrastructure. The Clean Cities Program includes partners from all aspects of transportation, including transit agencies. Many of the transit agencies surveyed for this report are stakeholders in their local Clean Cities coalition. These agencies can benefit from the program through the information provided on alternative fuels, vehicles, and infrastructure.

A recent program established for Clean Cities coalitions can help with some of the difficulties in implementing AFVs and infrastructure. The Clean Cities Technical Assistance (Tiger Teams) Project employs teams of experts to aid in solving technical problems with vehicle operation and infrastructure, as well as evaluate opportunities for alternative fuel projects. Coalition members can request assistance for their particular problem through the Clean Cities Web site, http://www.ccities.doe.gov/tiger.html.

There are several projects in progress that relate directly to transit applications. They include:

- AFV Transit Training Resource Guide,

- Fact sheet on the Transit Users Group, and

- Facility specifications to help a transit agency to add CNG buses to their fleet.

\section{American Public Transportation Association}

http://www.apta.com

APTA Alternative Fuels Committee: http://www.apta.com/cmmtt/altfuel/altfuel.htm

APTA Electric Bus Subcommittee: http://www.apta.com/cmmtt/buseq/elecbus.htm 
Codes and Standards: The National Fire Protection Association publishes codes and standards to minimize the possibility and effects of fire and other risks. For information on codes applicable to natural gas vehicles and infrastructure, visit http://www.nfpa.org/Codes/index.asp

Codes specific to natural gas include:

- NFPA 52 Compressed natural gas vehicular fuel systems code

- NFPA 55 Standard for the storage, use, and handling of compressed and liquefied gases in portable cylinders

- NFPA $57 \quad$ Liquefied natural gas vehicular fuel systems code

- NFPA 59A Standard for the production, storage, and handling of liquefied natural gas

- $\quad$ NFPA 88 Standard for repair garages

\section{American National Standards Institute}

http://www.ansi.org/

DOE Field Operations Program

http://www.ott.doe.gov/otu/field_ops/field_ops.html

DOE AFV Fleet Buyer's Guide

http://www.fleet.doe.gov

DOE Office of Transportation Technologies

http://www.ott.doe.gov

AFV Training Providers: http://www.ott.doe.gov/education/training.html

U.S. Department of Transportation Congestion Mitigation/Air Quality (CMAQ) Program http://www.fhwa.dot.gov/environment//cmaq/eligblty.htm

Alternative Fuels Data Center

http://www.afdc.doe.gov

California Air Resources Board

http://www.arb.ca.gov/homepage.htm

Transit Bus Program: www.arb.ca.gov/msprog/bus/bus.htm

Federal Transit Administration

http://www.fta.dot.gov/

Altoona Bus Testing

http://www.vss.psu.edu/fta/index.htm

College of the Desert Training Program

http://desert.cc.ca.us/ettc/index.html

Natural Gas Vehicle Institute

http://www.ngvi.com/html/about.html

Transit Users Group (sponsored by DOE and NGVC)

Dennis Smith, DOE, 202-586-1791, dennis.a.smith@ee.doe.gov 


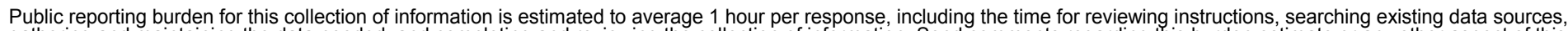

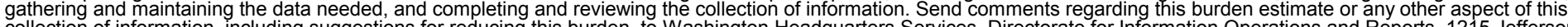
Davis Highway, Suite 1204, Arlington, VA 22202-4302, and to the Office of Management and Budget, Paperwork Reduction Project (0704-0188), Washington, DC 20503.
1. AGENCY USE ONLY (Leave blank)
2. REPORT DATE
February 2002
3. REPORT TYPE AND DATES COVERED
Technical Report
4. TITLE AND SUBTITLE
6. AUTHOR(S)
Leslie Eudy
7. PERFORMING ORGANIZATION NAME(S) AND ADDRESS(ES)
National Renewable Energy Laboratory

Natural Gas in Transit Fleets: A Review of the Transit Experience

5. FUNDING NUMBERS

FU23.5620

8. PERFORMING ORGANIZATION REPORT NUMBER

9. SPONSORING/MONITORING AGENCY NAME(S) AND ADDRESS(ES)

National Renewable Energy Laboratory

1617 Cole Blvd.

Golden, CO 80401-3393

AGENCY REPORT NUMBER

NREL/TP-540-31479

11. SUPPLEMENTARY NOTES

NREL Technical Monitor: Leslie Eudy, Richard Parish

12a. DISTRIBUTION/AVAILABILITY STATEMENT

National Technical Information Service

12b. DISTRIBUTION CODE

U.S. Department of Commerce

5285 Port Royal Road

Springfield, VA 22161

13. ABSTRACT (Maximum 200 words)

Use of natural gas in transit bus fleets has grown over the last decade. Often motivated by air quality concerns, the use of natural gas also contributes to national and local energy security. Approximately $9 \%$ of the U.S. transit fleet in 2001 was composed of buses operating on some form of natural gas and even more were on order. While some agencies have achieved success with their natural gas programs, others report difficulties and some have suspended their natural gas use altogether. What makes an agency successful in implementing natural gas into their operations? This paper reviews the experience of agencies with natural gas to determine the answer and to provide guidance on how fleets can effectively duplicate the successes and address or avoid the challenges.

14. SUBJECT TERMS

Natural gas; buses; transit; fleets; challenge; success

15. NUMBER OF PAGES

16. PRICE CODE

17. SECURITY CLASSIFICATION

OF REPORT

Unclassified
18. SECURITY CLASSIFICATION OF THIS PAGE Unclassified
19. SECURITY CLASSIFICATION OF ABSTRACT

Unclassified
20. LIMITATION OF ABSTRACT

UL 